\title{
An Assessment and Mapping of Gully Erosion Hazards in Abia State: A GIS Approach
}

\author{
Peter Chigozie NWILO \\ Department of Surveying and Geoinformatics, Faculty of Engineering, University of Lagos, Lagos- Nigeria \\ Tel: 234 (0)8035725644Ｅ-mail: pcnwilo@unilag.edu.ng; pcnwilo@yahoo.com \\ Dupe Nihinlola OLAYINKA \\ Department of Surveying and Geoinformatics, Faculty of Engineering, University of Lagos, Lagos- Nigeria
}

Tel: 234(0)8125720725Ｅ-mail: dsaka@unilag.edu.ng

Ibeabuchi UWADIEGWU

Department of Geography, Faculty of Social Science, University of Lagos, Lagos- Nigeria

Tel: 234(0)80654345364 E-mail: domegacometh@yahoo.com

Ayila Emmanuel ADZANDEH

Department of Surveying and Geoinformatics, Faculty of Engineering, University of Lagos, Lagos- Nigeria

Tel: 234(0)701111392Ｅ-mail: ayilaj@yahoo.com

Received: June 13, 2011

Accepted: July 12, 2011

doi:10.5539/jsd.v4n5p196

\begin{abstract}
The issue of gully erosion is of major concern in the south-eastern part of Nigeria. This study adopts Geographic Information Systems (GIS) as a tool to identify and study gully erosion hazards in Abia state. 171 gully erosion sites were coordinated using GPS receivers and overlaid on the soil and geological maps of the study area. Spatial database for erosion sites was created using relational database model. Additional 35 gully erosion sites were identified from the processed digital elevation model (DEM) and ground verification carried out. Result shows that gully erosion sites were well dispersed around false bedded sand stone geological formation. The slope characteristic was ascertained to be greater than $15^{\circ}$ which encourages gully erosion activities. An erosion hazard map was produced showing risk and vulnerability of settlements and infrastructure. This study shows that GIS is an efficient and effective tool in the study and mapping of gully erosions.
\end{abstract}

Keywords: Gully erosion, Hazard, GIS, DEM, Erosion mapping, Abia state

\section{Introduction}

In the past three decades, gully erosion has been an issue of concern in the southeastern part of Nigeria and Abia state in particular. Erosion by its nature is one of the geomorphologic process that affects an area (Goudie, 1990). It is a nightmare to both motorist and pedestrians who use this road daily. There have been reported cases of cars lorries fallen into these gullies. As of today, most of these erosion sites have completely cut off roads and extended beyond the diversion points which sometimes leaves no space for further diversion. In an unpublished report submitted by Nwilo and Asangwe in 1994 to NEST/Ford Foundation, that gully erosion is by far the most alarming type of erosion in the Southeast of Nigeria.

Gully erosion occurs primarily as a result of rain drop impact, washing away by running water which creates rills that later develop into gullies. The different activities of man without regards to the conservational laws are manifested by the degrading of the soil by the process of weathering and erosion. Until 150years ago Southeast Nigeria was covered by thick rainforest (IRIN, 2011). Erosion (gully) occurs in various patches in the South-Eastern states of Nigeria. Erosion problems arise mainly from natural causes but their extent and severity are increasingly being attributed to man's ignorance and unintentional action (Enabor and Sagua, 1988).

Figure 1.1: The expansion of gully erosion along foot path near farmland. 
In spite of technological advancement, erosion menace still remains a major problem in Nigeria (especially in South Eastern Nigeria). The yearly heavy rainfall has very adverse impacts altering existing landscape and forms. Such landforms create deep gullies that cut into the soil. The gullies spread and grow until the soil is removed from the sloping ground. Gullies when formed expand rapidly coupled with exceptional storm or torrential rain down the stream by head ward erosion gulping up arable lands, economic trees, homes, lives, sacking of families (Umudu, 2008) and valuable properties that are worth millions of naira. As a matter of fact, there is a direct correlation between development and the effect of gully erosion in Abia State. Figure 1.1 shows a typical erosion site.

In the tropics and semi-arid regions, the ever abiding presence of gullies are seen. This is however associated with traditional agricultural practice seen in that area (FMANR,1990). Beside the evacuation of farmlands through the excessive removal of the top soil, bridges, roads, telecommunication, railway line and electric poles are continuously washed away and rivers including silted streams.

Figure 1.2: Eroded sites in Amaokwe Community, Abia State.

It is worthy to note that conservation measures depend upon a thorough understanding of the mechanics of the erosion processes. Physical and human factors should however be put into consideration.

Gully erosion always starts unnoticed and certainly not when it takes place slowly. The results are remarkable in terms of loss of land and properties. About $45 \%$ of the eastern states are affected by measurable sheet erosion while about $20 \%$ of land surface suffers from severe sheet erosion. There is a dearth of studies on recent changes in landforms due to erosion in the south-eastern part of Nigeria. Past researches reveal that the Agwu-Nanka gully complex alone accounts for a physical loss of over nine hundred and thirty (930) hectares of agricultural land (Ofomata, 1964; 1981and Grove, 1951a)), while about 7.5\% of Oko village was occupied by gullies Grove (1951b). This study is an attempt at feeling the gap.

In Abia State, most affected communities are Amakama, Uturu, Ekenaobizi, Ohiya, Amaokwe, Amayi, Amuzukwu and Umuajata (Figure 4.1). Landslides and gullies have caused untold hardship on the people of these communities which have consequently resulted in loss of financial and material resources. This has made the bid of the people to attain self-sufficiency in local production of food and agro based industrial raw material almost impossible. Chukwuedozie and Arinze (2011) documented that gully erosion menace has over the years been responsible for increasing losses of houses and land of the people, thereby displacing affected inhabitants. Also, it has led to the loss of life of people and livestock, as well as the destruction of farms on which the majority of the population depend for survival. There is the urgent need to solve erosion problem in Abia state or at least reduce its impacts on the environment before more valuable lands are lost to gully erosions.

Land is an important resources and factor of production (Adalemo,1993). Gully erosion in Abia State is one of the major land degradation problems (Enuvie,2010) which still stand between the government, rural areas, and the final victory against hunger. In the bid to answer the above question one has to consider this urgent and critical question that deserves an answer. Is it that the government and community are not really doing much to combat this problem? Also, is this phenomenon following a particular geological or relief trend? What about the soil type and other human activities, are they really responsible for the development of gully erosion and landslide in Abia State? It is in realization of these problems and questions that this study was undertaken as a modest effort in highlighting and solving this problem of gully erosion in the study area. Gully erosion has had and will continue to have destructive impact in and around the southeast of Nigeria in the absence of immediate corrective and preventive measures (Acho, 2006).

The government releases fund each year to reduce and combat the challenges resulted from effects of the gully erosions. The question is why do efforts in combating and conserving the environment, prove to be abortive and above all, can this war be won?

\subsection{Objectives}

Specifically, the study has the following objective:-

- Identify the distribution of gully in the study area using GIS.

- Examine the causes of gully erosion and spotting areas affected by gully erosion.

- $\quad$ Examine the consequence (hazard) of gullies on the overall development in the study area.

- $\quad$ Possible control measures to take in the area with a view of making recommendations to solve the (gully) erosion problem. 


\subsection{Location and Geology of Study Area}

Abia State lies between longitude $07^{\circ} 00^{\prime}$ and $8^{\circ} 09^{\prime}$ North, and latitude $06^{\circ} 00^{\prime}$ and $04^{\circ} 45^{\prime}$ East. The State is located east of Imo State and shares common boundaries with Anambra, Enugu and Ebonyi States to the North West, North and North East respectively. To the East and South East, it is bounded by Cross River and Akwa Ibom States and by Rivers State to the South. It occupies a landmass of 5,833.77 square kilometres (Figures 1.3 and 1.4). The State is about 596 kilometres from Lagos and about 498 kilometres from Abuja. Abia state comprises of seventeen (17) local government areas.

The rock system and geological history of this area are due to events that took place between Mesozoic and Cenozoic eras respectively. Her structure is divided into three namely, Upper coal measure, False-bedded sand stones, and Lower coal measure. The upper coal measure formation is the largest geological formation in this region. It comprises mainly of coarse grains, alternating sediments of grey sands, dark shale which contains sands of impure coal in place of vertical horizon.

Figure 1.3: Map of Abia State and seventeen local Governments.

Figure 1.4: Towns and Road Network in Abia State.

Figure 1.5: Geological map of Abia State

\subsubsection{Rainfall}

Abia experiences a high rainfall with corresponding high discharge of water as runoff that encourages gully erosion. It has a peak period between July and September (Figure 1.6). In a study conducted by Jimoh (2005), rainfall events were found to be highly correlated to erosion in all the representative land surface types.

Figure 1.6:- Mean distribution of Rainfall from 1972-2010

\section{Socio - Economic Impacts of Gullies in Abia.}

The effect of gully erosion in this region is tremendous. Here are the major impacts of gully erosion:

- Displacement of Large Population of People: In Isuikwato LGA, the entire Communities in Amaokwe, Abia State University, Uturu, Ogudasa, Oruruala were completely displaced due to the expansion of gully sites. The Amuzukwu community in Umuahia North L.G.A of Abia State suffered the same fate. In Abia state, the road that links Abirbia and Ohaifa communities as well as Ohiya Expressway are badly affected.

- Destruction of Houses: cracking of houses and falling of buildings into gully sites are common features in the erosion prone areas. People have lost their life investments into gullies in areas like Amaokwe, Ogudasa, Oruruala, and so on in Abia State. People have become refugees in their ancestral homes. The damage on the psyche of these people cannot be quantified.

- Destruction of Roads and Transport Infrastructures: The major federal highways in the areas have been virtually destroyed in many portions or completely cut off. Examples are (a) Enugu - Port Harcourt Expressway at Ohiya (b) Enugu - Port Harcourt Expressway at Ntigha near Umuahia (c) Abirbia-Ohaifa Road in Umuahia North L.G. A of Anambra State and (d) Ugba-Nkata Road in Umuahia North L.G. A of Abia state (e) Ugba - Mbalano Road in Isuikwato LGA. (Figure 4.7)

\subsection{Gully Erosion Management}

The loss due to gully erosion and landslide has increased demand on the land for agriculture and other human activities. This calls for the application of landscaping and other measures such as channelization of floodwater, Geoinformation - Based Early Warning System (GEOBEWS), tree planting and erection of concrete breakers to mention a few in protecting and preserving the environment. No serious thoughts have been given to peri-Urban agricultural land. These measures, particularly landscape planning can be employed in tackling gully erosion in Abia state and at the same time create a functional, attractive, livable and beautiful environment.

To achieve the above, the following landscape elements are required; trees, shrubs, grasses, walls, buffers, rocks, and gravels. Economic and non-economic tree should be used, which can be hewn and replaced at intervals. For shrubs, approved seeds and fast growing leguminous grasses that can restore worn out soil nutrients as a result of erosion should be used.

\section{Methodology}

Geographic information System (GIS) combines data management and analysis of large volume of geographically related data. 


\subsection{Data Acquisition}

The data collected for the study are classified into primary and secondary data. The primary data are coordinates of already existing gully sites obtained from GPS observations during reconnaissance survey of Abia State and attributes data during oral interview. Secondary data source includes information on rainfall distribution from January to December, 1972-2007 collected from records of Meteorological Department of National Root Crop Research Institute (NRCRI). Existing vegetation/land use, geology, rainfall, relief, road and soil maps printed and published by ministry of lands, survey and urban planning, Umuahia, Abia state from 1980-date were collected. The elevation data (DEM) and contour map of Abia State for 2009 was derived from Advanced Spaceborne Thermal Emission and Reflection (ASTER) (Figure 1.7).

\subsection{Data conversion}

Available paper maps where scanned to digital/raster image. The scanned maps were georeferenced and digitized in ArcGIS software environment.

Figure 3.1: Contour Map of Abia State obtained from ASTER

3.3 Spatial Analysis using GIS

\section{Operations:}

- Map Overlay- combination of two separate spatial data sets (points, lines or polygons) to create a new output vector data set.

- Spatial Query- a query was built by choosing a Field, then an Operator, then a Value.

- Feature Identification on GIS - each layer in an ArcMap has a table storing attributes about the geographic features it contains.

- Buffering- a geographic buffer is the area that contains all features that are closer or equal to a specified buffer distance from the boundary of a feature or set of features. This was used to buffer towns affected by erosion and next affected town putting in mind rate of erosion runoff.

- Nearest Neighbor Statistics- the average nearest neighbour distance tool was used to measures the distance between each feature centroid and its nearest neighbour's centroid location. It then averages all of these nearest neighbour distances. If the average distance is less than the average for a hypothetical random distribution, the distribution of the features being analyzed are considered clustered. If the average distance is greater than for a hypothetical random distribution, the features are considered dispersed. The index is expressed as the ratio of the observed distance divided by the expected distance (expected distance is based on a hypothetical random distribution with the same number of features, covering the same total area). Hence if the index is less than 1, the pattern exhibits clustering; if the index is greater than 1, the trend is toward dispersion. This was to examine the distribution points in the study area (Abia state).

- Geostatistics is a point-pattern analysis that produces field predictions from data points. It is a way of looking at the statistical properties of those special data. The Geostatistics wizard was used to produce prediction map (using ordinary Kriging) Erosion hazard map (in the study area).

\section{Results and discussion}

The application of GIS in gully erosion study cannot be over emphasized. One hundred and seventy one gully erosion sites were identified in Abia State and coordinated during field work. From the processed ASTER data, thirty five additional gully erosion sites were located (Figure.4.1). Further verification (ground truthing) confirms that those points were actually gully erosion sites.

Figure 4.1: Gully Erosion Sites in Abia State

The result obtained from average nearest neighbour analysis shows that the distribution of gullies in Abia State is dispersed, with a $\mathrm{z}$ score $=\mathbf{2 . 5 1 1 7 3 2}$ at significant level of 0.05 (Figure 4.2)

Figure 4.2: Nearest Neighour Analysis Results.

The index showed that the distribution of gullies in the area is clustered. The following factors could be responsible as evident from the questionnaire and oral interviews:

(i) Human component: Bad agricultural practice, removal of vegetation cover, poor drainage and road construction and excavation.

(ii) Physical component: These include soil type, slope characteristics, and rain storm. 
An overlay of erosion sites on the geological map of the study area reveals that majority of the erosion sites are located on false-bedded sand stone which is porous or loose, frisk with the palm, and does not retain its shape like clay which has high level of plasticity. The fragile nature of the soil makes it prone to erosion (Figure 4.3). Loose disposition of soil in a local environment makes it susceptible to the forces erosion (Jimoh, 2008).

Figure 4.3: Digital Elevation Model of Abia State obtained from ASTER

The erosion site was also overlaid on the soil map (Figure 4.4) and it reveals the following characteristics:

- Weak structure, very friable and highly leached,

- Moderately to imperfectly drained and poor

- Erosion high

- $\quad$ PH value : between 4.8 and 5.3

- Slope steep

- Moderate (orthoxic tropoduct- rhodic ferralsols (red ferralsol), typic tropoaifs-eutric nitrosols(s) and high orthoxic tropoduct- rhodic ferralsols (red ferralsol).

The study area is characterized by a steep slope with slope greater than $15^{\circ}$ (Figure 4.4). The slope was calculated using surfer8. Also, a 3D elevation was built (Figure 4.3). The slope of Abia State was found to be $17^{\circ}$, and it favours erosion activities. This is as a result of the great kinetic energy gained at the plane with the highest slope angles. The energy increases downward thereby carrying eroded materials from deep incision made from those points. About $35 \%$ of the gully erosion sites have slope angles greater than $18^{0}$ while a moderate slope (less than $15^{\circ}$ ) dominate the rest.

\subsection{Gully Erosion Expansion}

Buffering was done at different distances to show the rate of encroachment of gully in the study area. Gully erosion flows at a rate of $450 \mathrm{~kg} / \mathrm{ha} / \mathrm{yr}(45000 \mathrm{~kg} / 0.01 \mathrm{~km} / \mathrm{yr})$, based on this for every $1 \mathrm{~km}$ buffer $45000 \mathrm{~kg}$ of soil is eroded. Figures 4.5 and 4.6 show buffer map at 600 and 1200 meters. This shows that the menace of erosion is one that requires urgent attention.

Also, from 1980-1990 (a space of 10years) $1 \mathrm{~km}$ radius of soil is eroded $(45000 \mathrm{~kg}$ ). This increases as the distance increases (as 600 and $1200 \mathrm{~m}$ buffer). This reveals the extent of coverage engulfed by erosion at specified distance as towns and villages are eaten up, farmland swallowed, and communication disrupted( Figure 4.7).

Figure 4.4: Spatial queries for areas of high porosity, instable, and liable to erosion in Isukwuato (areas highlighted with verged blue)

Figure 4.5: Erosion site overlaid on Slope analysis map of the study area.

The buffering carried out serves as a tool for checking rate of encroachment of gully erosion in the area. It helps in determining gully erosion hotspots and next possible site (including settlements, roads, farmland, and other infrastructure) to be affected. This also helps in proper gully erosion management and control. In general, it helps to simulate and forecast future trends of gully erosion.

Figure 4.6: A buffer distances of 600 and 1200m around Erosion site in the Study Area

Figure 4.7: Spatial buffer for settlement and roads at risk in Abia South

\subsection{Gully Erosion Hazard Map Generation}

Areas of potential gully were mapped using weight overlay in ArcGIS environment. The input parameter for the Hazard map were vegetation /land use map, geology map, rainfall map, relief map (slope), road map population density, and soil map. Rate of influence and level of erosion was determined (in percentage), using the parameters in Table 4.4. The gully erosion hazard map is shown in Figure 4.8(b).

Table 4.1: Parameter value used for analysis

Figure 4.8: (a) Analysis of weight overlay operation, (b) Gully Erosion Hazard Map.

\section{Conclusion}

The causes of erosion in the study area are both anthropogenic (human causes) and natural factors. GIS approach allows for overlays of these factors, allowing identification and location of gully erosion sites and infrastructures which are affected. A conceptual background of causes, problems and consequences of gully erosions were $\mathrm{x}$-rayed in cognizance to the peculiarity of the Abia region as regards her weather and climate, geologic and hydrologic traits or indifferences. A Near Neighbour Analysis Result shows that gully erosion sites were well 
dispersed around false bedded sand stone geological formations. The slope characteristic was ascertained to be greater than $15^{\circ}$ thereby encourages gully erosion activities. An erosion hazard map was produced showing risk and vulnerability of settlements and infrastructure. This study shows that GIS is an efficient and effective tool in the study and mapping of gully erosions.

We recommend structural and non-structural landscaping measures as good control and management techniques to check continuous gully erosion problems and its impacts . A more practical approach at the local level, with respect to control of farming practice, enhanced aforestation, prevention of bush burning and overgrazing would go a long way in reducing the problems and consequences of gully erosion in Abia State and Nigeria in general.

\section{References}

Acho Orabuchi (2006). Erosion in Nigeria: Calamity in the waiting. Dallas, Texas, USA. aorabuchi@netzero.net [Online] Available: http://www.kwenu.com/publications/orabuchi/2006/3erosion_calamity.htm) (Accessed: April 20, 2010).

Adalemo, I.A. (1993). Land Management in Nigeria in Adalemo, I.A.and Baba, J.M. (Eds) Nigeria. Giant in the Tropics, Volume 1: A Compendium (Gabunoi Publishers, Lagos), pp. 77-80.

Chukwuedozie Kelechukwu Ajaero and Arinze Tagbo Mozie (2011). The Agulu-Nanka Gully Erosion Menace In Nigeria: What Does the Future Hold for the Population at Risk? Climate Change and Migration: Rethinking Policies for Adaptation and Disaster Risk. Institute for Environment and Human Security United Nations University, Munich Re Foundation from Knowledge to Action. Studies of the University: Research, Counsel Education- publication series of UNU-EHS. No.15/2011pp74-81. [Online] Available: http://www.ehs.unu.edu/file/get/8468

[Online] Available: http://cis.uchicago.edu/outreach/summerinstitute/2011/documents/sti2011-warner-rethinking_policies_for_adapt ation_and_disaster_risk_reduction.pdf

Enabor, E.E. and Sagau, V.O. (1988). Ecological Disasters in Nigeria: Soil Erosion (An Introduction) in Sagau, V.O., Enabor, E.E., Ofomata, G.E.K., Ologe, K.O, and Oyebande Lekan (Eds) Ecological Disasters in Nigeria: Soil Erosion ( Federal Minisry of Science and Technology, Lagos) pp. vii-xv.

Enuvie G. Akpokodje, Akala , C. Tse, and Nnamdi Ekeocha (2010). Gully Erosion Geohazards in Southeastern Nigeria and Management Implications. Science Africa, Faculty of Science, University of Port Harcourt. Vol.9 (No.1), March 2010, pp20-36

Federal Ministry of Agriculture and National Resource, Lagos (1990): Literature Review on Soil Fertility Investigations in Nigeria, Vol.5, Bobma Publishers, U.I.O, Box 955-5, Ibadan, Pp.16-22.

Goudie , A. (1990). The Human Impact on the Natural Environment (Basil Blackwell Ltd., Oxford, U.K.) Chapter 9, pp. 203-229.

Grove, A.T. (1951a). "Land Use and Soil Conservation in parts of Onitsha and Owerri Provinces". Geological Survey of Nigeria, Bulletin No. 21, pp79

Grove, A.T. (1951b). "Soil erosion and population problems in Southeast Nigeria", Georgia Journal. pp117, 191206.

IRIN (2006). Nigeria: Erosion Imperils many Southeast Communities. Humanitarian News and Analysis. IRIN AFRICA.

http://www.irinnews.org/report.aspx?reportid=61492 (accessed 14 January, 2011)

Jimoh, H. I. (2005). Tropical Rainfall Events on Erosion Rate in a Rapidly Developing Urban Areas in Nigeria. Singapore Journal of Tropical Geography. Department of Geography, National University of Singapore. Blackwell Publishing. Volume 26, Number1, 2005. http://onlinelibrary.wiley.com/doi/10.1111/j.0129-7619.2005.00205.x

Jimoh, H. I. (2008). Effects of River Erosion on Houses: A Case Study of Asa River Catchment in Ilorin, Kwara State, Nigeria. Medwell Journals. The Social Science3 3(2): 193-195, 2008. ISSN: 1818-6125

http://www.medwelljournals.com/abstract/?doi=sscience.2008.193.195

Ofomata G. E. K. (1981). "The Land-resources of South-eastern Nigeria:- A need for Conservation". In Igbozurike U. M. (Ed) Landuse and Conservation in Nigeria, Nsukka, UNN Press. 
Ofomata G.E. K. (1967). "Some observations on relief and erosion in Eastern Nigeria" Revenue de Geomorphologic Dynamique, Vol.17, No.1, P.22-29.

Umudu, M. (2008). Residence Flee as Erosion Eats up Anambra Community. In: The Nation. Monday, October 20, 2008. Vintage Press Ltd, Lagos.

Table 4.1 Parameter value used for analysis

\begin{tabular}{|l|l|}
\hline Erosion Rate & Value \\
\hline Low & 3 \\
\hline Moderate & 2 \\
\hline High & 1 \\
\hline
\end{tabular}

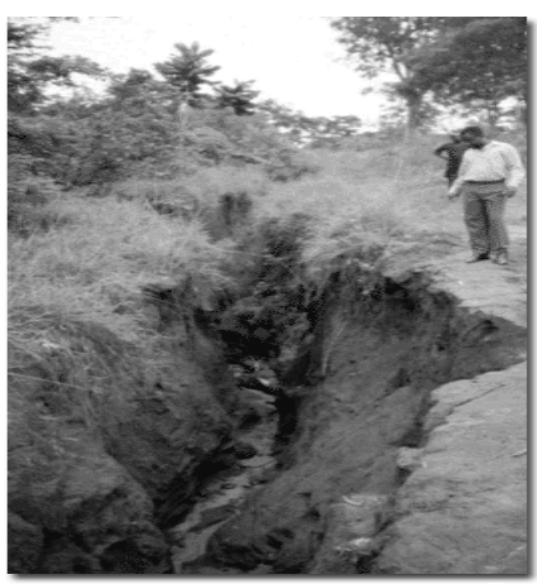

Figure 1.1 The expansion of gully erosion along foot path near farmland
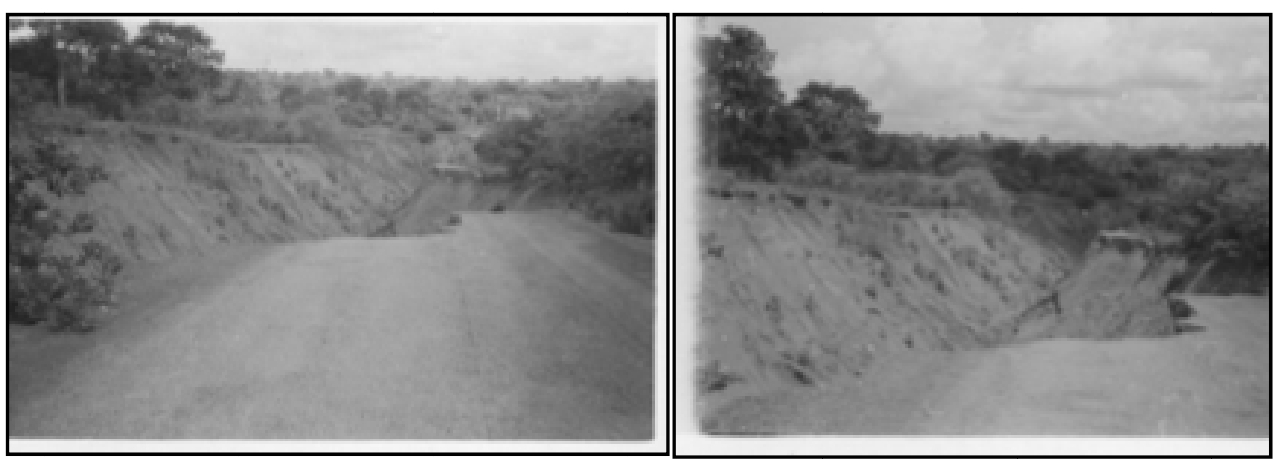

Figure 1.2 Eroded sites in Amaokwe Community, Abia State 


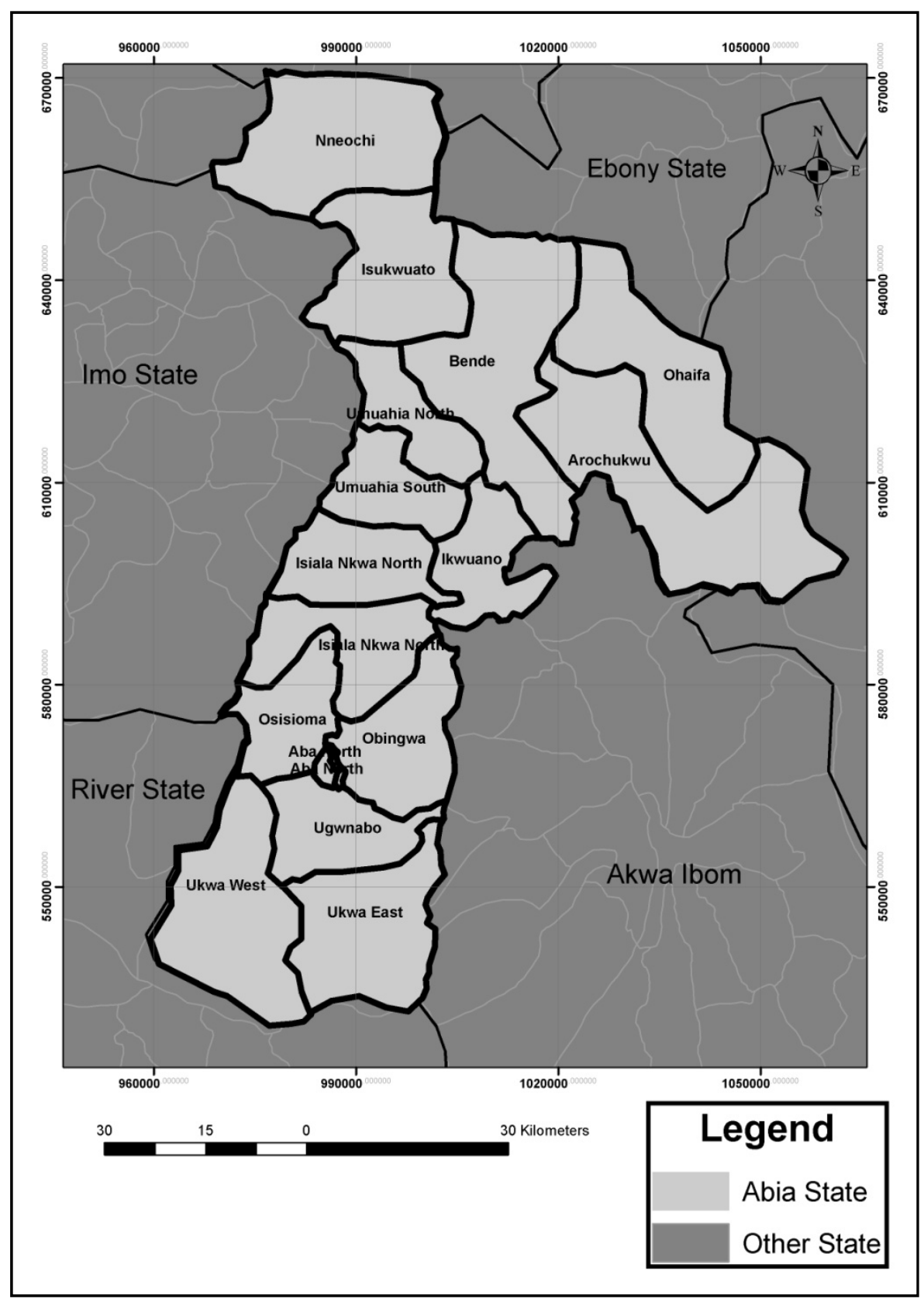

Figure 1.3 Map of Abia State and seventeen local Governments 


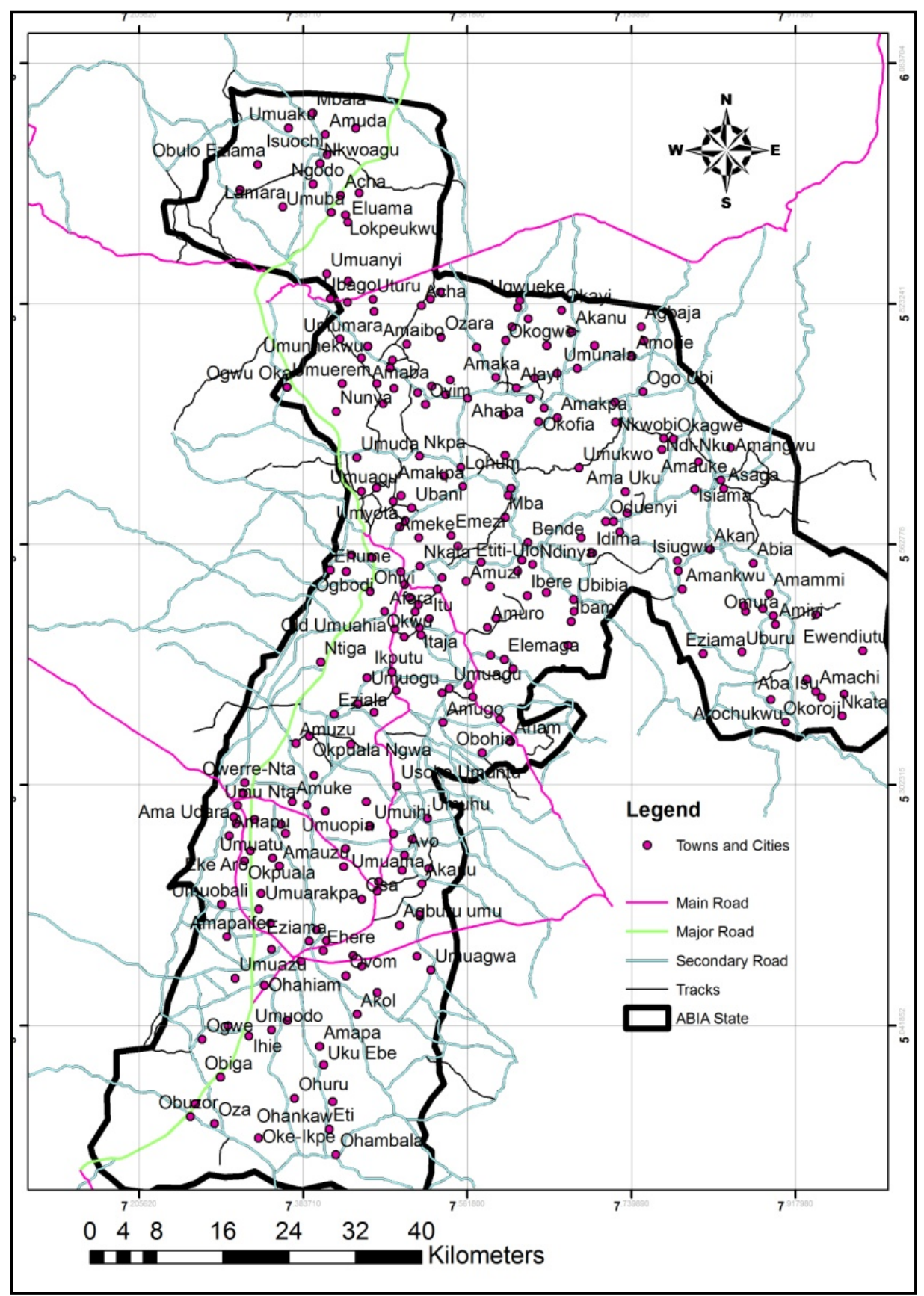

Figure 1.4 Towns and Road Network in Abia State 


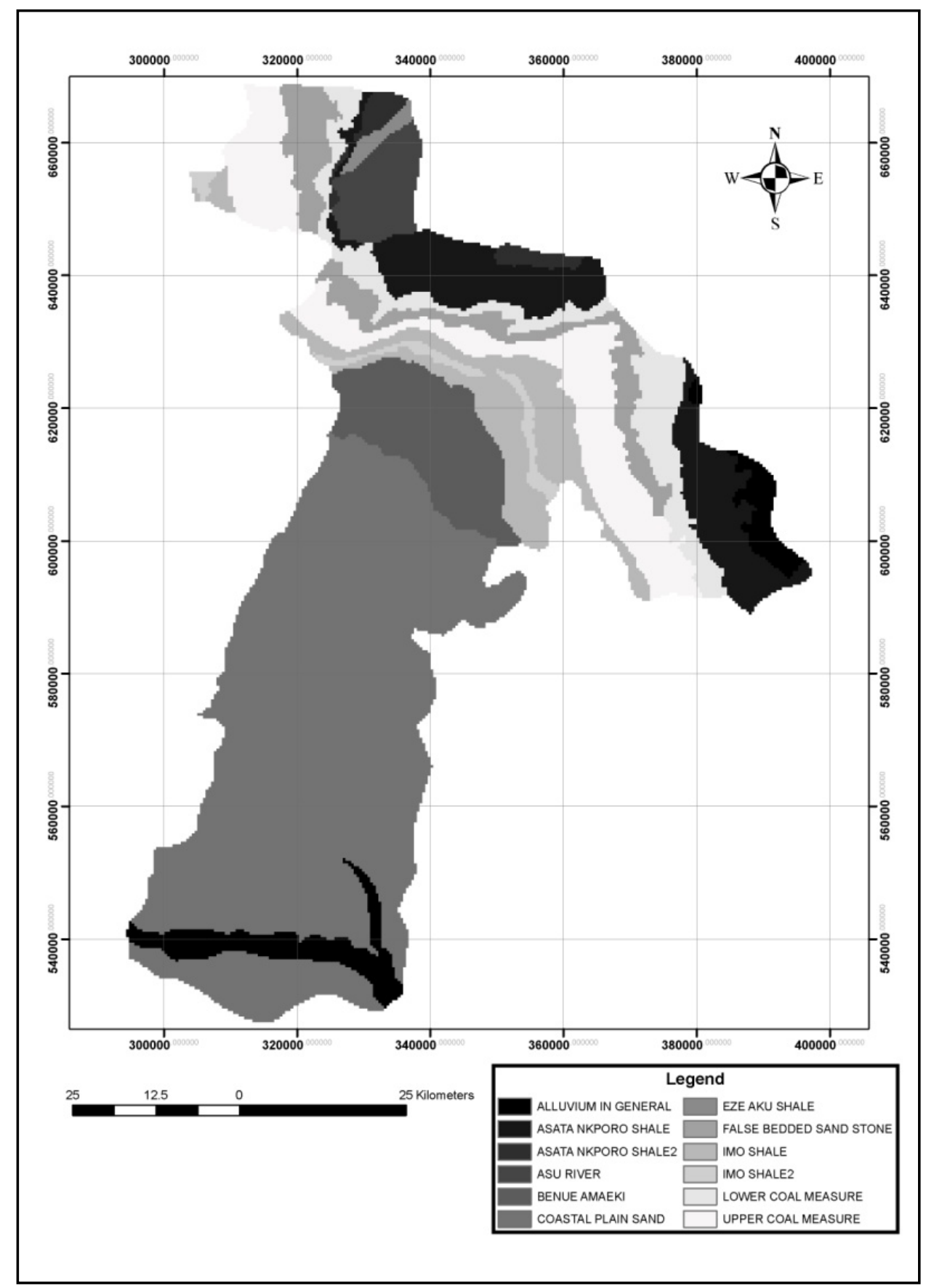

Figure 1.5 Geological map of Abia State 


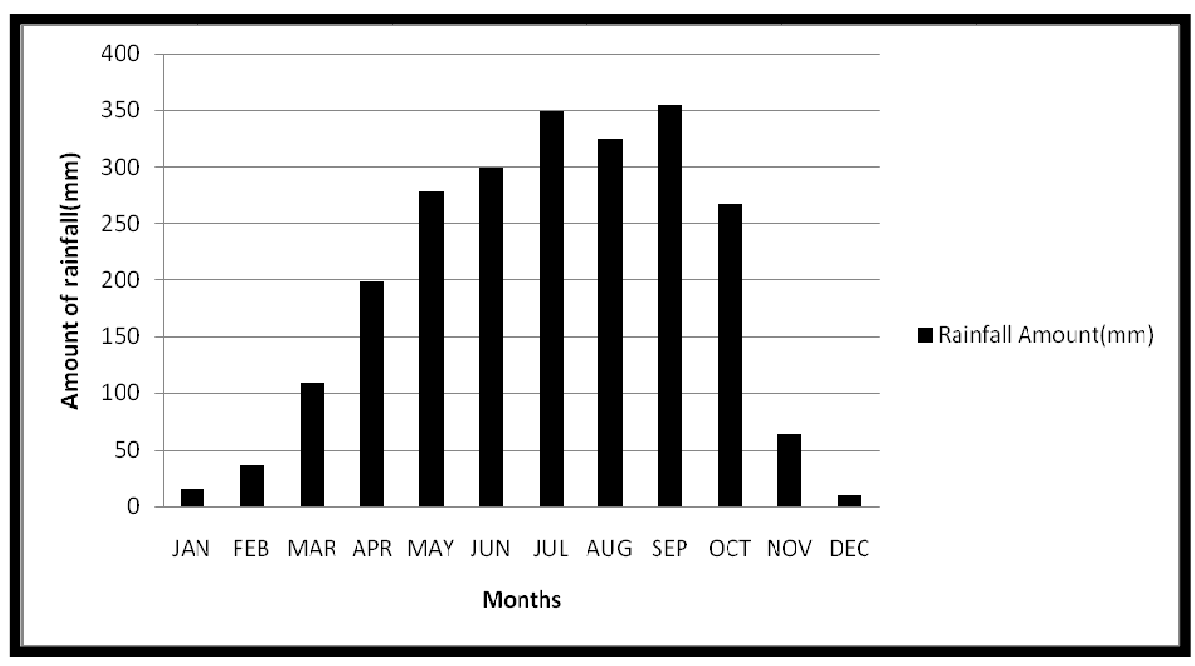

Figure 1.6. Mean distribution of Rainfall from 1972-2010

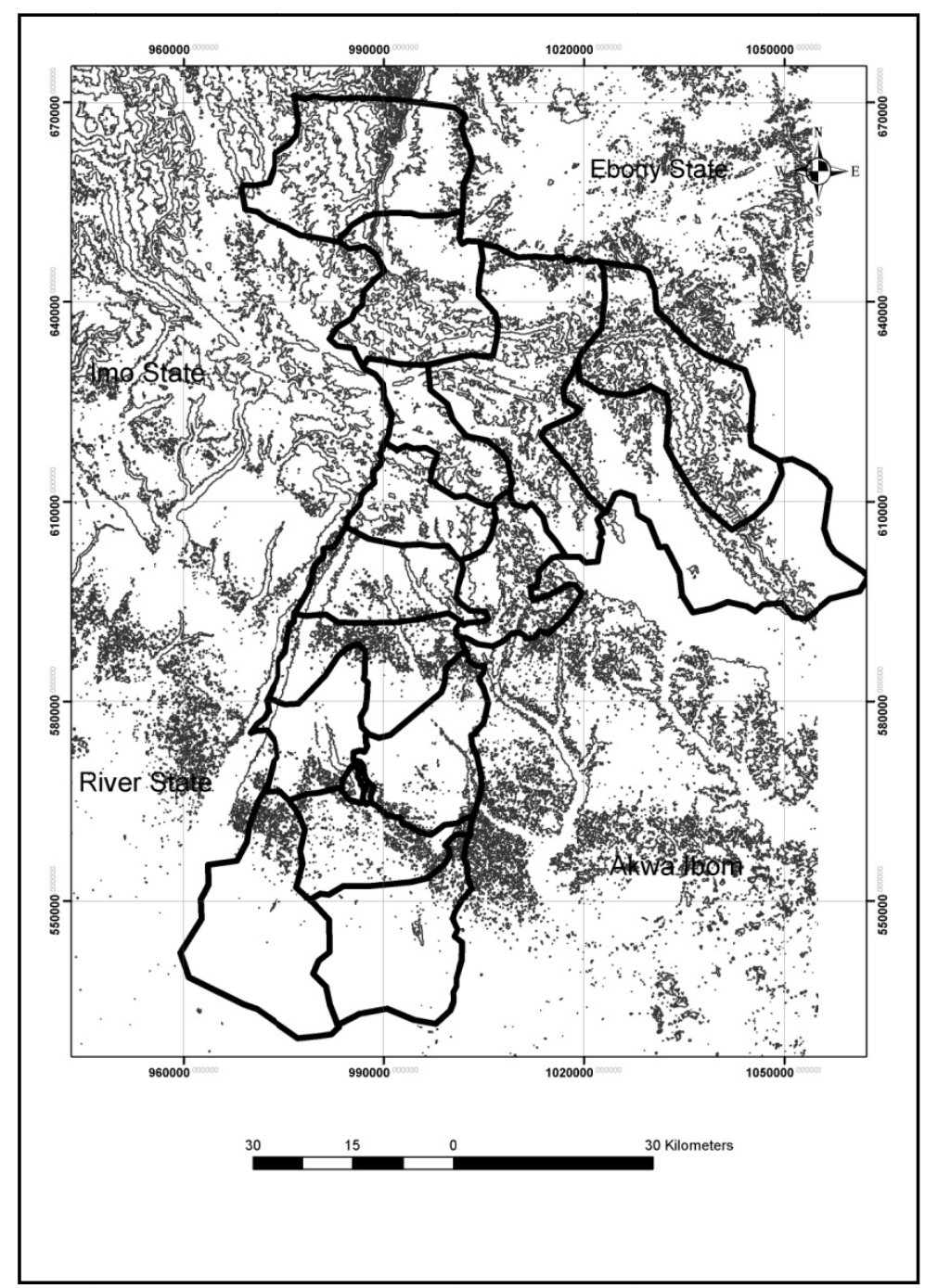

Figure 3.1 Contour Map of Abia State obtained from ASTER 


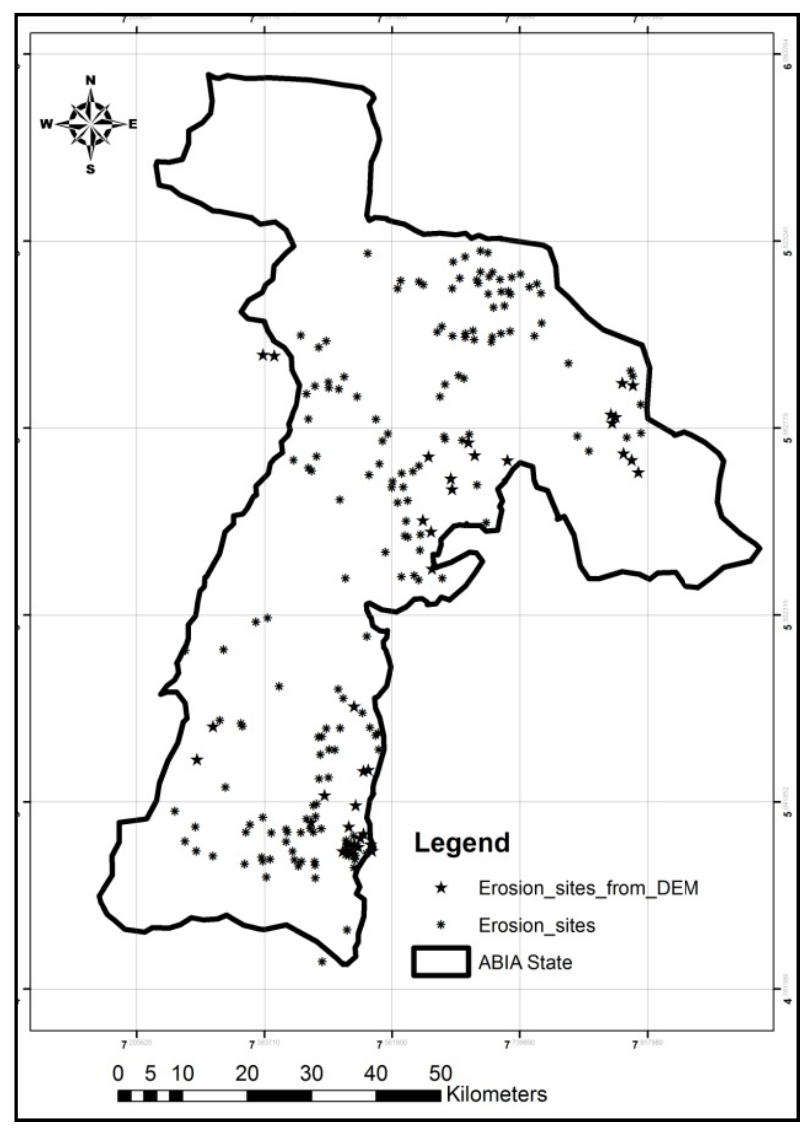

Figure 4.1 Gully Erosion Sites in Abia State

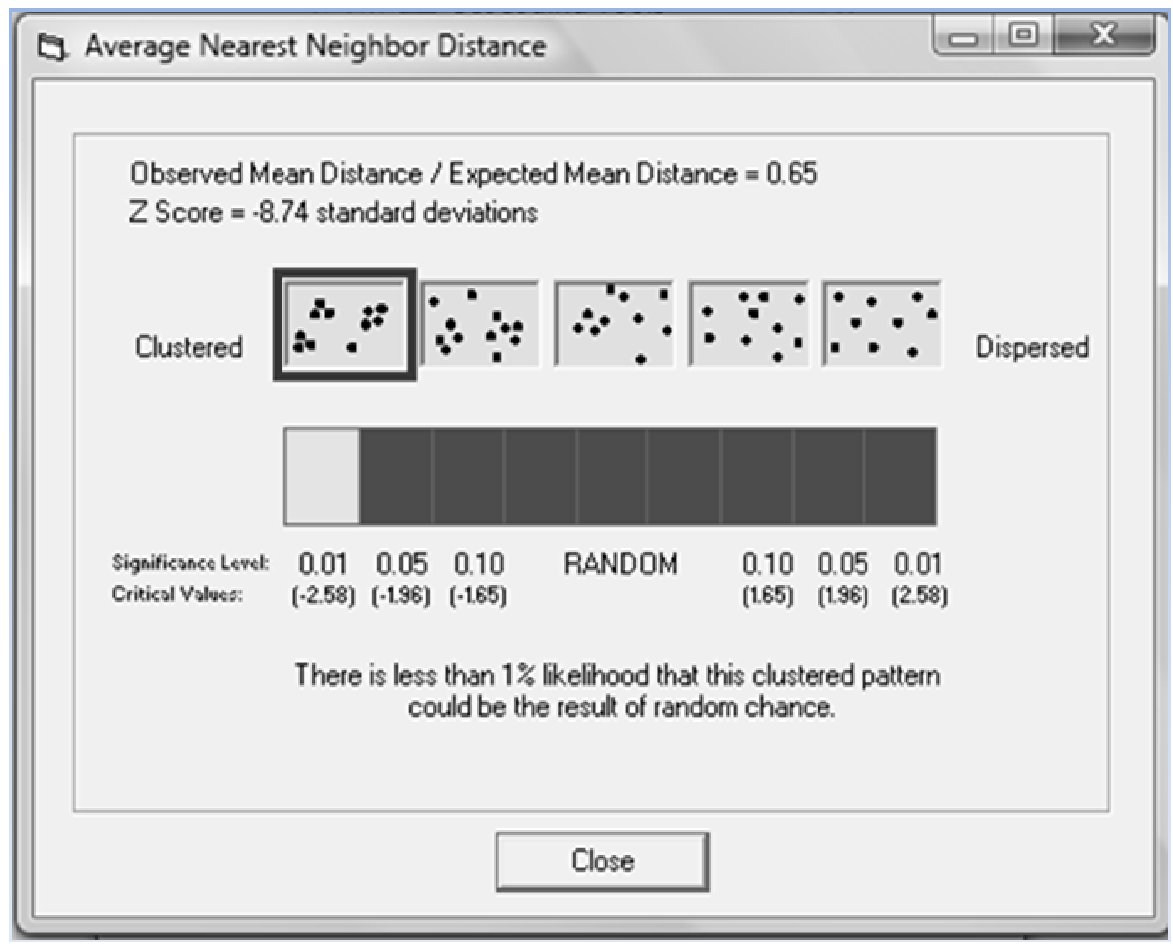

Figure 4.2 Nearest Neighour Analysis Results. 


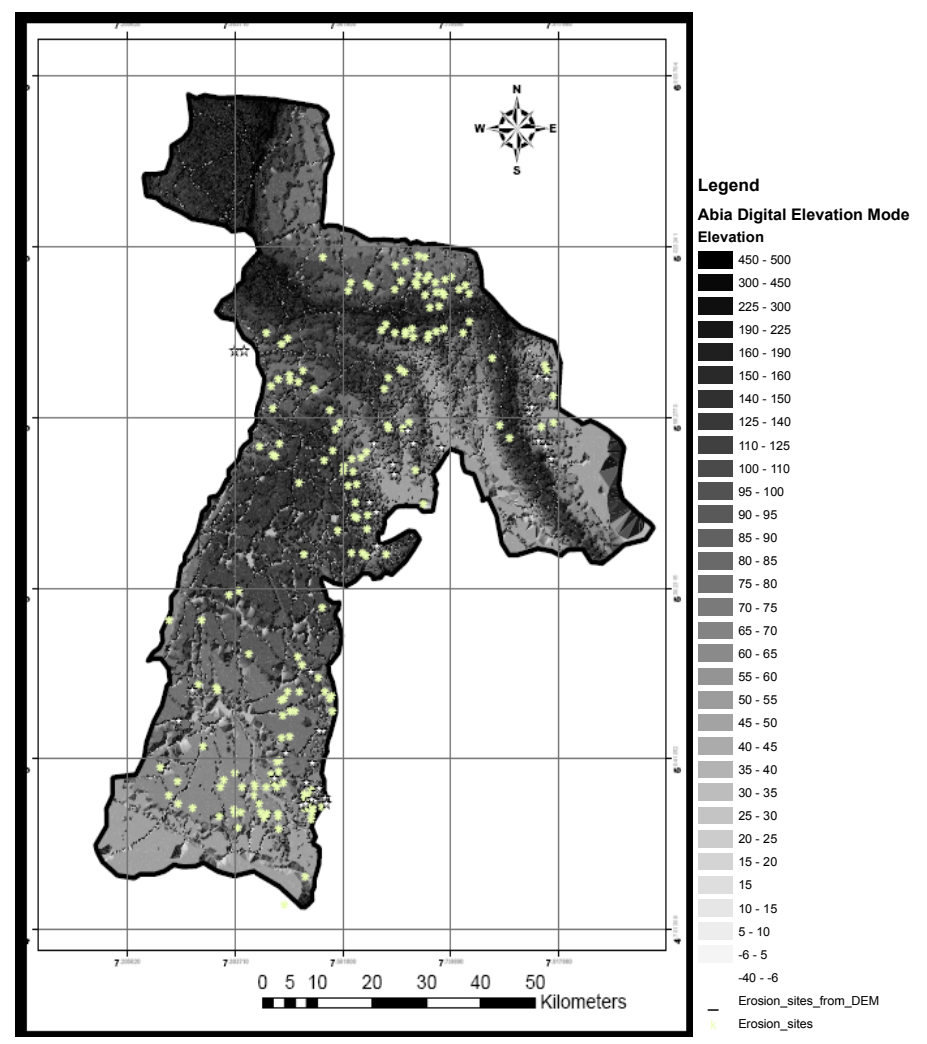

Figure 4.3 Digital Elevation Model of Abia State obtained from ASTER

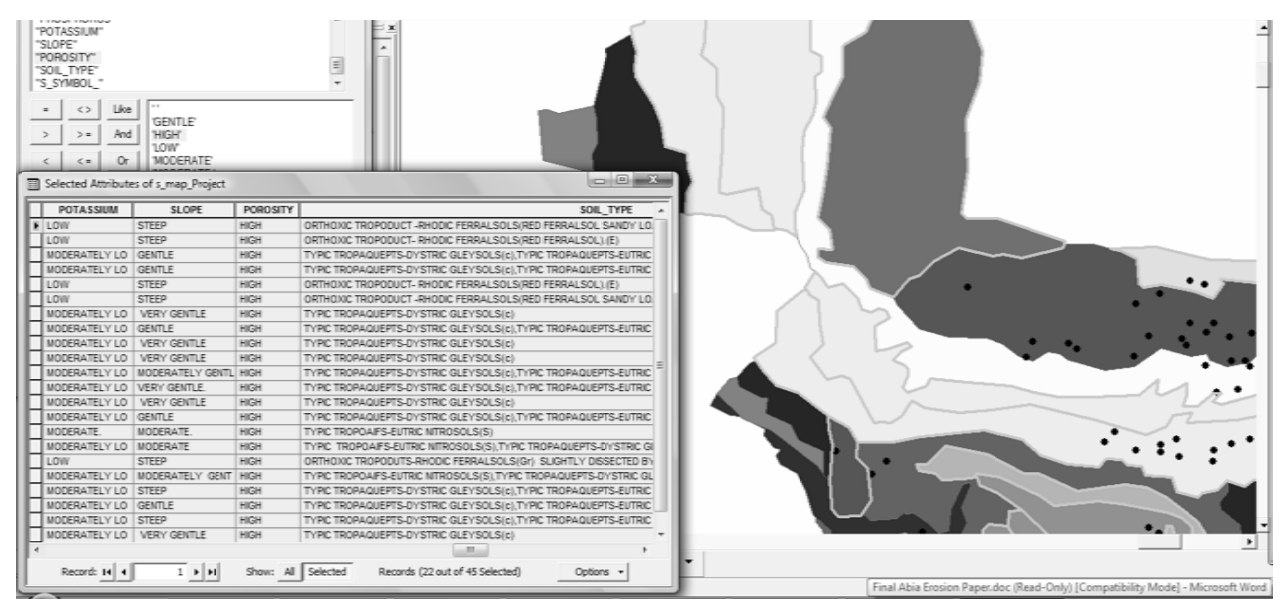

Figure 4.4 Spatial queries for areas of high porosity, instable, and liable to erosion in Isukwuato 


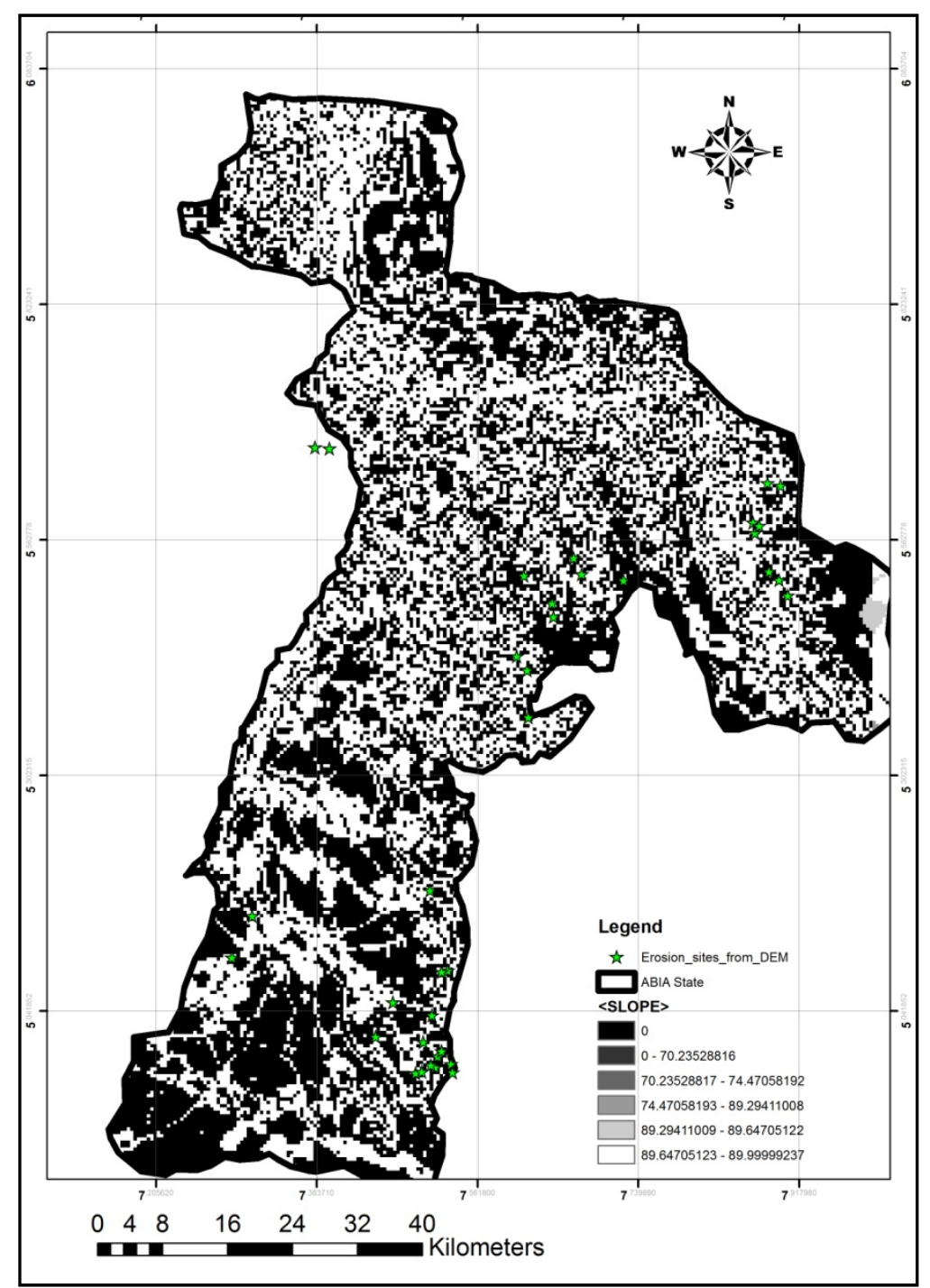

Figure 4.5 Erosion site overlaid on Slope analysis map of the study area 


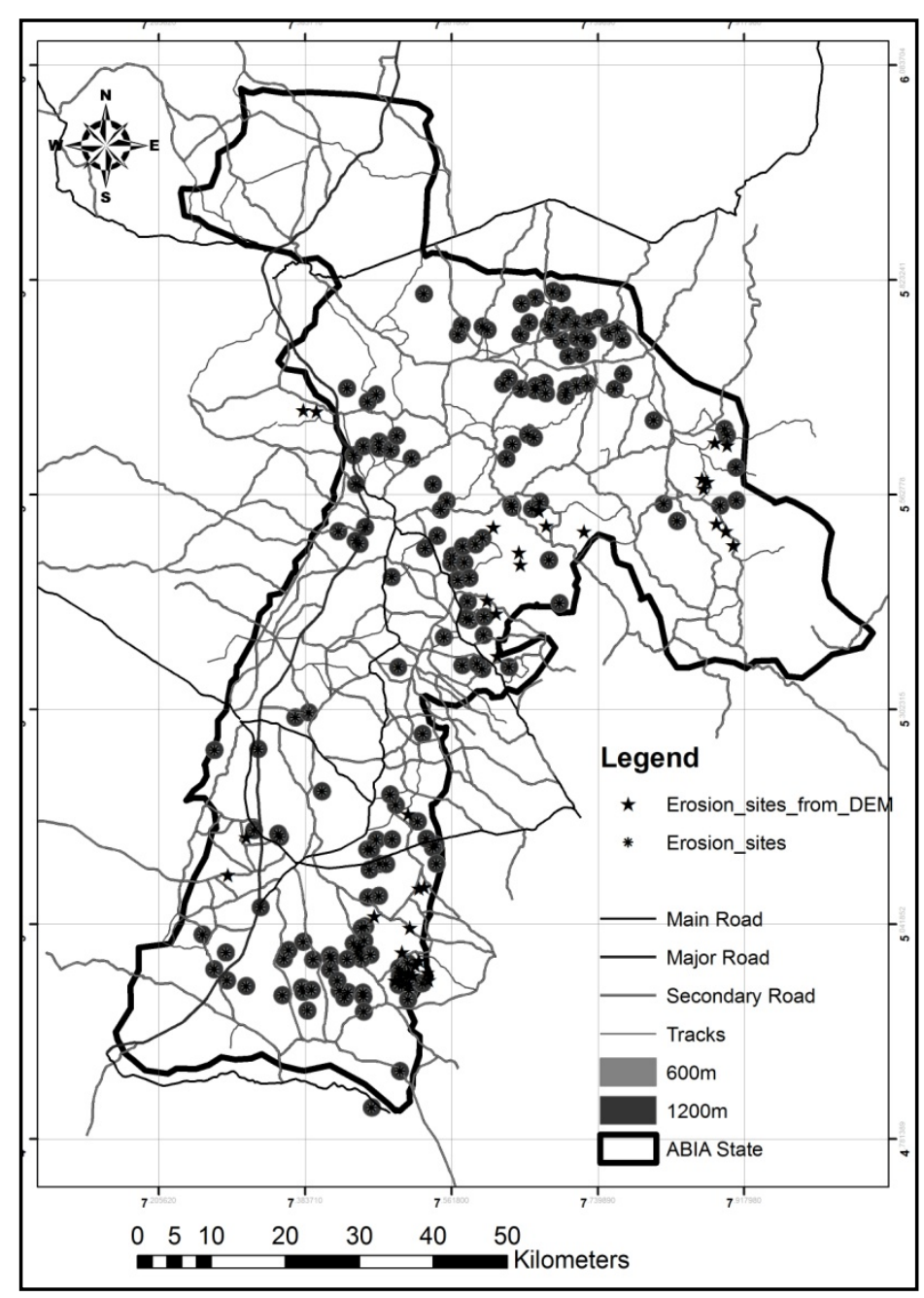

Figure 4.6 A buffer distances of 600 and 1200m around Erosion site in the Study Area
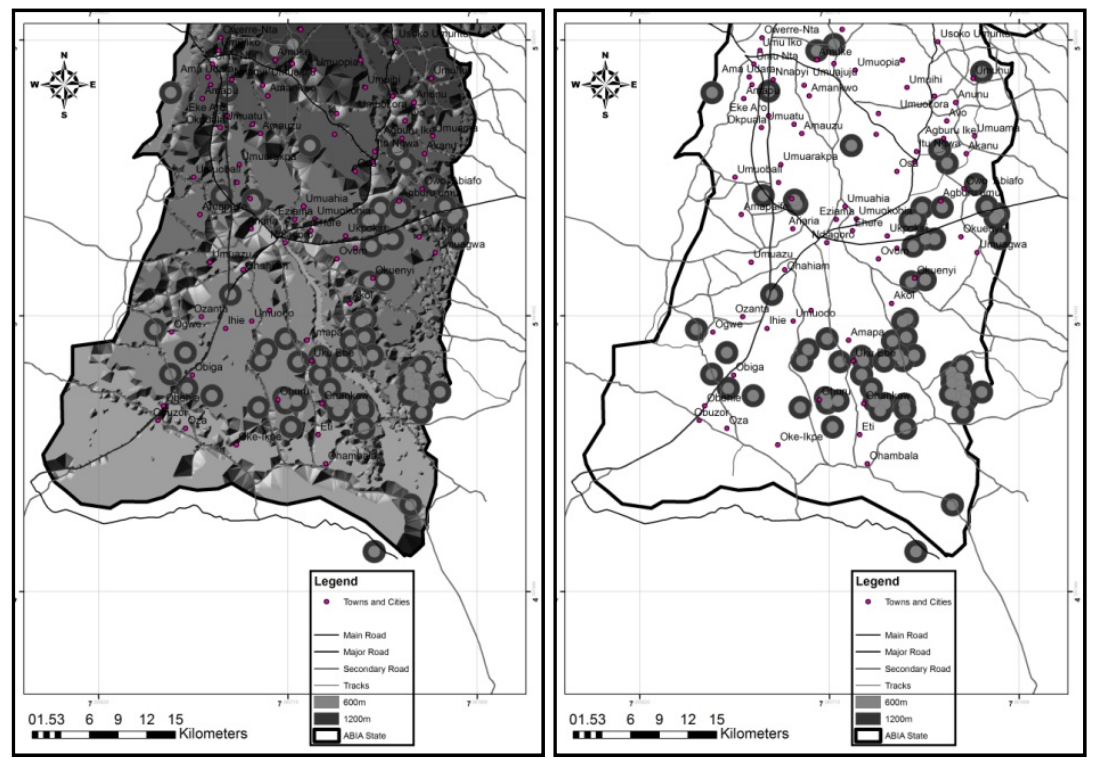

Figure 4.7 Spatial buffer for settlement and roads at risk in Abia South 


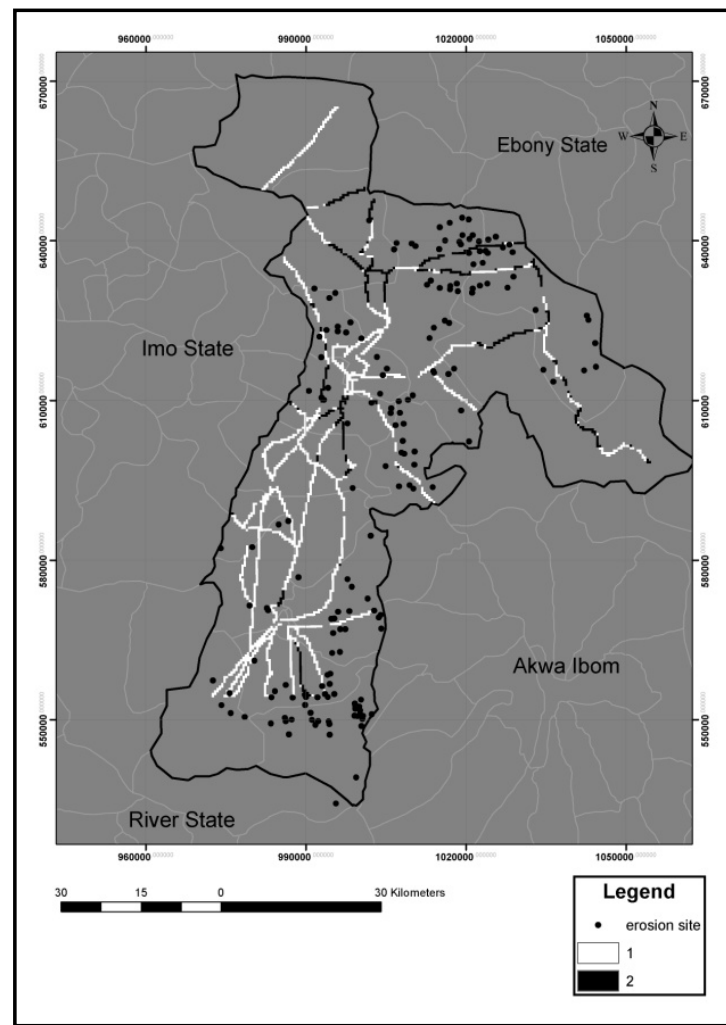

(a)

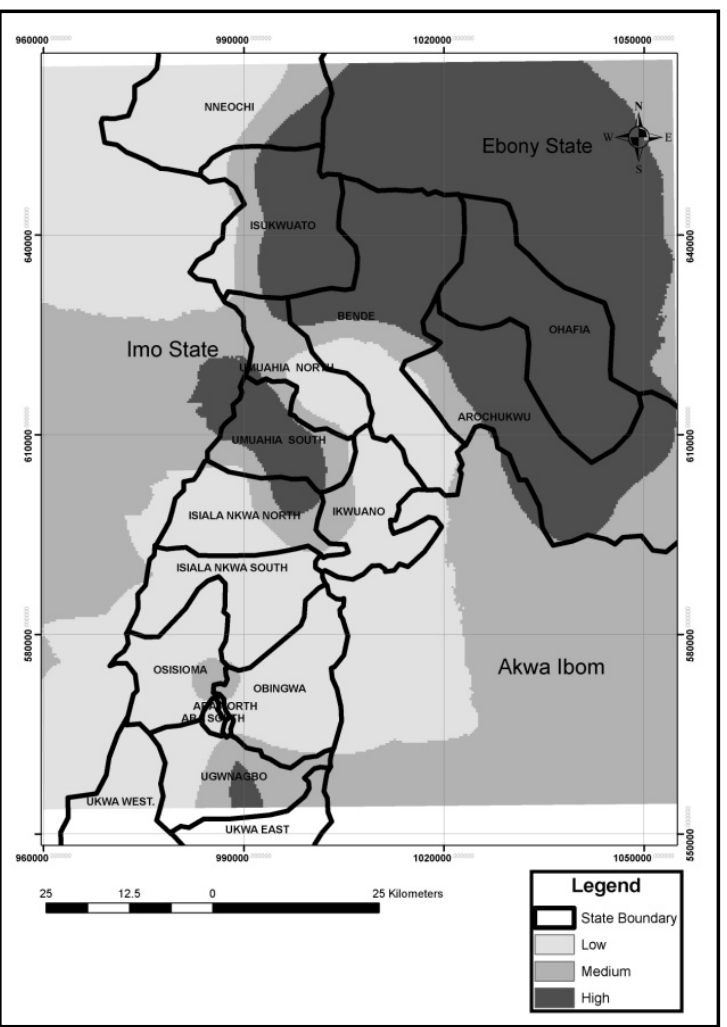

(b)

Figure 4.8 (a) Analysis of weight overlay operation, (b) Gully Erosion Hazard Map 